\title{
LEVELS OF POVERTY AND THE POVERTY GAP IN RURAL LIMPOPO
}

\author{
RR Mears \& PF Blaauw, University of Johannesburg ${ }^{1}$
}

\begin{abstract}
Purpose/objectives: The aim of this paper is to obtain a better understanding of the income and expenditure patterns of selected deep rural villages. This is done by measuring the level of poverty and/or the poverty gap of 132 households in Limpopo, one of the poorest provinces in South Africa.
\end{abstract}

Problem investigated: The Millennium Declaration symbolises the commitment to end extreme poverty, but limited data is available for rural areas to inform policy decisions. The relative income shares for individuals, households and percentile groups within a population provide the best information on poverty for policy formulation. The nature and size distribution of income are therefore central to analysing the poverty problem within low-income areas. The survey area is one of the poorest areas in South Africa, and shows what data is needed to measure and understand the extent of poverty.

Design/Method/Approach: A representative sample of 132 households was drawn, which represents 6,9 percent of the estimated 1900 households in selected villages of rural Limpopo. A total of 740 household members were represented in the survey, with an average of 5,6 members per household.

Originality/Value: Although this is a relatively small sample, it generated much-needed data on this very poor area of South Africa. Detailed empirical data on the income and expenditure patterns is not available, especially for rural areas. The socioeconomic data from this research supported an important health project of the Water and Health Research Unit (WHRU) of the University of Johannesburg. The article also lays the foundation for further research in this field of study, facilitating engagement with a number of related debates such as those about satisfaction of life, vulnerability to poverty, the geography of deprivation and the mapping of poverty.

Conclusion: The main finding is that the government provides for many needs of the poor, especially in the deep rural areas. Only 18 percent of the sample households did not receive a state grant in 2007. This was an injection of R88 800 or 33,4 percent of the total income per month, which excludes the social wage in terms of free basic water, electricity, subsidised or free housing, health care subsidies and other support to poor people and rural communities. Of the 485 non-economically active people in the sample, more than 364 or 75 percent receive an income, mainly in the form of state grants. Education suggests itself as a route out of poverty, rather than the child grant and other subsidies that encourage poor people to have more children. Poor couples and single-member households fall through the safety net, because they do not qualify for state grants and have no children yet.

Key Words: Income patterns, expenditure patterns in rural areas, level of poverty, poverty gap.

\section{INTRODUCTION}

The Millennium Declaration in 2000 symbolises the commitment to end extreme poverty. This development requires a higher Gross National Income (GNI), and hence sustained growth for the majority of poor people. Moreover, widespread poverty, high or even growing income inequality is at the core of most development problems. The relative income shares of individuals, households and percentile groups within a given population provide the best information on poverty for policy formulation (Todaro and Smith 2009:208). The income inequality of those above the poverty line gives a better understanding of the depth of poverty and the impact of market and policy changes on the poor. An understanding of the nature and size distribution of income is central to analysing the poverty problem within low-income areas of countries (Todaro and Smith

${ }^{1}$ Financial and logistical support for this project from the now-defunct Development Society of Southern Africa, the Professional Provident Society (PPS) and the Water and Health Research Unit (WHRU) at the University of Johannesburg is acknowledged and greatly appreciated. The helpful comments of two anonymous referees are also highly appreciated. The usual disclaimer applies. 
2009:238). Based on this, the most valid generalisations about the poor are that they are disproportionately located in rural areas, are mainly active in agriculture and associated activities, are more likely to be women and children than adult males, and are often concentrated among minority ethnic groups and indigenous peoples. Woolard and Leibbrandt (1999) showed that of those living in rural areas, 63 per cent are poor at a poverty line of R3 509 per adult equivalent per annum. The Eastern Cape and Northern (Limpopo) provinces have the largest number of poor people according to the head-count ratio and poverty depth measure (Bosch 2008:35). The survey area is precisely such a deep rural area in Limpopo, where poverty is a reality for many residents. Previous research showed that the plight of the poor increases the smaller and more rural the villages become (Mears, Jagals, Greyling and Blaauw 2008:23).

A more nuanced debate on the incidence, intensity and inequality in terms of poverty demands carefully executed micro-studies of different vulnerable communities. The aim of this study is to obtain a better understanding of the income and expenditure patterns of the selected deep rural villages by measuring the levels of poverty and the poverty gap of individual households and for the population as a whole.

The Vhembe District Municipality (VDM) is one of six district municipalities in the Limpopo Province. This district is situated in the northern part of the Limpopo Province, sharing borders with Zimbabwe in the north, the Kruger National Park in the east and Botswana in the northwest (VDM 2006:7). It comprises four local municipalities, namely, Makhado, Musina, Thulamela and Mutale. The Nwanedi River basin is situated largely in the area of the Mutale Local Municipality (MLM), and lies directly east of the Nwanedi Game Reserve. The white population in the MLM was 0,8 percent and the black population 99,2 percent in 2007. The MLM had a black population of 55 729, a white population of 460 and no Coloured, Indian or Asian people (StatsSA 2008a:2, 5 and 8; Mears et al. 2008:2).

This article analyses the income and expenditure patterns of the population under the following headings: literature review, research method, economic activity and expenditure in the villages, and the relationship between employment status and education levels. Moreover, the income and expenditure, Minimum Living Levels and the poverty gap in 2007 are also discussed, before the effects of state grants on the distribution of income are examined. The article concludes with the main findings and some tentative recommendations.

\section{LITERATURE REVIEW}

There is consensus in the literature that poverty remains one of the most pressing economic and social issues in South Africa, which explains why the South African government has as one of its goals to halve poverty by the year 2015. The debate on what constitutes poverty and how many poor people there are in South Africa is an ongoing one (Mohr 2010:165-166).

Poverty can be expressed in absolute and relative terms. Absolute poverty is when people are unable to afford a basic basket of goods deemed necessary for material survival. Such a basket is compiled on the grounds of nutritional and other requirements. The monetary value of such a package is then assumed to be a poverty datum line. Those with an income lower than that are considered to be poor (Mohr 2010:166). It is problematic to select an appropriate poverty line based on monetary terms, due to the subjective nature of distinguishing the poor from the non-poor on a mere monetary value. It is for example difficult to argue that a person with an income of R800 can be classified as poor, while a person earning R801 is not (Bosch 2008:20).

Relative poverty draws the line between the poor and non-poor by considering income relative to the overall distribution of income or to a median or average value. People whose income falls into the lowest 10, 20 or 40 per cent of incomes may be regarded as being poor. Relative poverty may vary from country to country. A person classified as poor in the United States of America may well be defined as relatively well-off in South Africa (Mohr 2010:166). 
Internationally, gross national income (GNI), as introduced and compiled by the World Bank, has for a long time been seen as the main instrument to measure poverty (Thirlwall 1999). The main argument for using this income method to specifically measure poverty is that, in theory, the basic purpose of development is to enhance people's choices. Unfortunately, increases in income levels are mostly restricted to the top income earners of a country and do not necessarily trickle down to grass-roots levels. Only the well-off tend to experience an increase in available choices. The drawback therefore to using a single GNI per capita income figure is that a country may be classified, in World Bank terms, as a high income country. However, in development terms it may struggle with low levels of human development, unequal income distribution as well as restricted choices (Bosch 2008:22-23). Despite the disadvantages, this measure, along with others, such as the 1990 World Bank measure of US $\$ 1$ a day, is still widely used today for comparative purposes (Mohr 2010:166; Bosch 2008:25; Todaro and Smith 2009:608).

Measures of inequality are used by economists to answer a wide range of questions. One example is whether the distribution of income has changed over a period of time. In spite of the widespread use of various measures, very little attention is given to conceptual problems involved in the measurement of inequality (Atkinson 1970:244).

Apart from international comparable measures of poverty, countries conduct independent research on poverty in order to create a poverty profile of the country. This research focuses on poverty as well as other related issues, such as inequality (Bosch 2008: 25). Most household and poverty-related information in South Africa can be gathered from various surveys, mostly done by Statistics South Africa. These include information on the living conditions, labour market status and other measures of living satisfaction. These are used by researchers in spite of the fact that sample frames and other methodological aspects differ. However, they provide the benefit of gathering vast quantities of descriptive information on an individual's poverty profile (Bosch 2008:26). A number of variables can be used to measure poverty from household surveys. These include per capita consumption, household consumption, per capita income, per capita food expenditure, per capita calorie intake, budget share of food expenditure and the average educational level of an adult household member (Woolard and Leibbrandt 1999; Bosch 2008:26). Several studies on poverty have confirmed the value of breaking down a population into subgroups. These can be defined along ethnic or geographical lines. The question of how the chosen poverty measure relates poverty in the subgroup to total poverty is crucial to its applicability in this form of analysis (Foster, Greer and Thorbecke 1984:761).

While most poverty measures rely on the poverty line, South Africa does not yet have a formal poverty line, although current efforts to develop an official poverty line are underway (Gumede 2008:3; Bosch 2008:36). Woolard and Leibbrandt (1999) further distinguish between absolute and relative poverty lines. An absolute poverty line does not change over time (the only exception to this being an inflation adjustment). A relative poverty line changes as the standard of living changes.

Different researchers identified various other measures in which a poverty line can be defined. One option is to look at the number of people who live in households that fall within the $20^{\text {th }}, 40^{\text {th }}$, or $50^{\text {th }}$ percentile cut-off of household per capita expenditure (Bosch 2008:36). Some researchers utilise expenditure brackets as used in Statistics South Africa's questionnaires: for example, R0-399 and R400-R799 (Meth and Dias 2003; Bosch 2008). An important addition is the possibility of using a poverty index. This is based on non-monetary values, such as the level of access to basic services, health care and finance (Bhorat, Naidoo and van der Westhuizen 2006).

Given the problematic aspects of choosing an existing poverty line, researchers have on many occasions estimated their own poverty lines. Income or, more often, consumption is used as a proxy for wellbeing and quality of life. However, poverty is a complex and a multi-dimensional socio-economic phenomenon. The Human Development Index (HDI) and the Capability Poverty Measure (CPM) emphasise the multi- 
dimensional nature of poverty (Magasela 2005; Gumede 2008:5). The definitions and measurements of poverty inform policies and programmes to alleviate poverty. As a result, the approaches to defining poverty are often dictated by the objectives thereof.

In South Africa there is not yet an official single definition of the poor, and various departmental definitions are applied instead. The most commonly used approach to setting poverty lines is the "cost of basic needs" approach, followed by the "food-energy intake" method (Gumede 2008:7-8). Ravallion and Lokshin (2006) and Gumede (2008:8) examine a number of technical issues pertaining to poverty lines and their lack of consistency. They define the poverty line as the income needed to achieve the minimum level of wellbeing required to be deemed not-poor. Therefore, the approach of this study is to incorporate different elements of the various available methods to allow for a nuanced analysis of rural poverty in the Limpopo Province.

The Bureau of Market Research at the University of South Africa discontinued calculating the Minimum Living Level (MLL) in 2004. However, the Business Intelligence Division of Global Insight provided its MLL estimates for 2007, which were used in calculations of the Gauteng Provincial Government (Bijker, 2008). These MLL estimates were slightly adapted for this study, to measure the poverty gap for the sample population (see Annexure 1).

Irrespective of the measure of poverty used, it is clear that the poverty situation in South Africa compares very unfavourably with that of other countries in the world with similar levels of per capita income (Tregenna 2010). The vulnerability of the South African poor in terms of poverty is amply illustrated by the fact that no less than 10 per cent of the South African population lives under the international comparative benchmark of less than a dollar per day. The corresponding value for countries in the world with similar levels of per capita income is two to five per cent (Tregenna, 2010).

\section{RESEARCH METHOD AND DESIGN OF THE SAMPLE}

The Minimum Living Levels (MLL) table in Annexure I was updated from 1996 data for inflation. This is the only available data based on the size of the household, and is similar to that used by the Human Sciences Research Council (HSRC 2004: Table 3). The MLL denotes the minimum financial requirements of members of a household to maintain an acceptable living standard, which is above the poverty line (Martins 2003:197). Given the expenditure items captured in Table 1, the cost of living is higher in rural than in urban areas, mainly because of the transport cost. Items that are cheaper in rural areas include payments for housing, rent, services and insurance, which most of the respondents did not use or received for free. These items are also free or significantly subsidised in poor urban areas. The difference in the cost of living in rural and urban areas provides the average for an area or province, but does not provide an accurate estimate for small villages or black townships. Although the living standards are lower in rural Limpopo than in Gauteng, the MLL was not changed for the reasons given.

The villages included in the survey were Folovhodwe, with an estimated population of 4500 , Shakadza (2 000), Gumela (505), Musunda (350), Tshitanzhe (250), Tshikotoni (50), Muswodi Tsisimani (2 000) and Muswodi Dipeni (2 500). This constituted a total estimated population of 12155 . A substantial number of the rural villages are not shown on official topo-cadastral maps, or they might appear on maps under very different historical names. In work for other projects, Global Positioning System (GPS) coverage of the area was done by the WHRU of the University of Johannesburg, specifically to pinpoint all households in the area. To obtain a representative sample of the households in the villages or a proportional coverage of the area in terms of population, the area was therefore divided into 44 blocks based on the GPS data. A total sample consisting of three households per block was drawn randomly from approximately 1900 households using a Microsoft Excel ${ }^{\circledR}$ randomising tool. In this way, 740 household members were represented in the survey, with an average of 5,6 members per household. The 132 households identified in this manner gave a coverage of 6,9 percent of the 1900 households. 
Ethical clearance for the project, which included the scrutiny and acceptance of an informed consent form, was obtained beforehand from the Research Ethics Committee of the Faculty of Economic and Financial Sciences of the University of Johannesburg. The questionnaire was adapted from the one used in Soweto in 1992 (Mears and Levin 1994). This was improved to enable the calculation of the poverty gap for each household in the sample. It was designed in conjunction with the Statistical Consultation Service (STATKON) of the University of Johannesburg.

The household was selected as the basic unit to interview. Preference was given to the household instead of the family unit, because the former includes both family and non-family members, thereby providing more reliable information. Households were defined in an economic sense as groups of people pooling their income to buy food, and who live, eat and sleep together in one or more houses, huts or living units on the same site and depend financially on one another (Mears and Levin 1994:7). In most cases, especially in rural areas where land is in ample supply, households consist of natural families. However, the definition was specified primarily to reflect information on socio-economic relationships and not on family size.

Postgraduate students from the University of Venda were used as TshiVenda-speaking fieldworkers and were trained before and during the survey. The questionnaire, an informed consent form as well as a field guide for the fieldworkers were translated into the local language, TshiVenda, and back-translated to ensure accurate and reliable translation. Students were trained to deal with refusals and in such cases substitute households in the same block were allocated. Most respondents cooperated willingly and only a few refusals were encountered, usually because the head of the household was not available to give permission for the survey.

Several unanticipated problems were experienced in the field. The main problem was that the people of the area speak only TshiVenda or expect to be addressed in their mother tongue. This resulted in slower interviewing, with fewer completed interviews than were planned. In the end only 132 of the planned 250 interviews were completed at more than double the estimated cost and time. However, these problems did not compromise the standard of the research.

Another difficulty was the lack of street maps with addresses. Despite all the houses in the whole area being waypointed by GPS, the houses still had to be found by means of GPS. This proved time-consuming, because houses were scattered over a large area and road access was not always possible. Moreover, the roads went over hills and through rivers, and some were tracks that were hardly navigable or visible. To counter some of these difficulties, blocks with three questionnaires at each waypoint were allocated to each fieldworker.

The completed questionnaires were cross-checked, and problems were identified and discussed with fieldworkers. Errors were corrected before the data were submitted for analysis. The following sections provide the results of the analysis.

\section{ECONOMIC ACTIVITY AND EXPENDITURE PATTERNS IN RURAL LIMPOPO}

The inadequate infrastructure, poor services and structural constraints to economic development in these villages hinder progress and development in these rural areas (Mears et al. 2008:16). Poverty is not measured by levels of unemployment only, but also by the lack of access to education, health care and basic services, such as water and sanitation (Makgetla 2004:15). Although there have been improvements in electricity and water provision during the period 1996 to 2007, many rural women are still economically disadvantaged. This is mainly because these services are unaffordable, especially in the rural villages (Mears et al. 2008:16). 
The survey area has many small communal landholdings or agricultural plots that are allocated to some of the residents. However, there is insufficient communal land available to allocate to all the households in the villages by the local headmen (Mears et al. 2008:20). Observations indicated that many economic and investment activities were taking place (Mears 2007). Many formal houses, mostly of the brick and tile-roofed kind, have been or are currently being built. Most of these houses are built on a cash basis as money becomes available for investment. This is confirmed by Table 2, which shows that only four households have loans. These loans total only R530 or R4 on average per month per household. The standard of housing differs significantly between members of the community, and some stands have only traditional round huts, built from mud and thatched roofs in the traditional manner.

Baobab trees in the villages and surroundings are well tended and harvested intensively by the local population. Most baobab fruits are harvested and sold for the production of oil for cosmetics and for other household uses (Mears 2007; Mears et al. 2008:22). However, the fact that very little or no coal is used has led to the destruction of most other types of trees in the area for firewood. Observations had revealed that along the main roads and near larger villages nearly all the trees have already been destroyed. This is in strong contrast with the baobab trees, which cannot be used for firewood and are a source of income.

Due to the sensitivity of respondents or households to divulge their income this question was asked only towards the end of the questionnaire and covered various forms of income. However, the expenditure was recorded in detail to obtain a reasonable estimate or proxy for this amount. Even then the data were not always forthcoming as expected, as in the case of the 35 households that stated that they spend nothing on clothing. Although 81 households spend nothing on schooling and the rest very little, two households with children in private schools spend R1 250 and R5 000 per month respectively. Only one household pays R100 in property taxes, while another one pays R70 for the maintenance of the garden. Two respondents pay for a Telkom telephone, totaling R30 per month, which is less than the basic rental for this service. Some items were not included in Table 2, because of the small amounts involved, and were included under other expenses.

Fieldworkers asked each respondent about all his or her expenditure items. Therefore, the total observations were 132 or 100 percent in every instance. Table 1 gives a detailed account of the expenditure in the rural villages and confirms the level of poverty. Row 1 shows that nine respondents spent between $R 1$ and $R 100$, and spent R691 in total on maize meal. A substantial percentage of the respondents do not use milk, other energy or transport, cigarettes and tobacco and alcoholic drinks. Only a few households pay for water and electricity, and rent or spend on medical services, insurance, licences and gambling, or make savings. No adjustments were made for people using their own produce of milk and meat. Questions about income and expenditure on agriculture were, however, included to capture these items.

The total expenditure was R174 544 or R1 322 on average per month for the 132 households in 2007 . This is an average expenditure of R236 per person for the 740 members. This translates into an average of R15 864 per annum. This is well below the national average in terms of the latest available figures. The results of Statistics South Africa's Income and Expenditure Survey 2005/2006 show that the total annual household consumption expenditure during the survey year was estimated to be approximately R700 billion. On average, the estimated total consumption expenditure per household in South Africa was R56 152. The main components of household consumption expenditure were on items such as housing, water, electricity, gas and other fuels; transport; and food and non-alcoholic beverages (Statistics South Africa, 2008b: 3). As a population group, black African households spent a much larger percentage on food than the other population groups. Almost one in every three rand $(30,2 \%)$ of the total household consumption expenditure of black African households was spent on food, beverages, clothing and footwear; while white households spent approximately one in every ten rand $(11,1 \%)$ of their consumption budget on the same items in 2005/06 (Statistics South Africa 2008b:6). 
In this rural area the most significant expenditure item was food. The largest expenditure is on their staple diet of maize meal at R32 232, or 18,5 percent of the total expenditure. Maize meal is followed by other food with R16 789, clothing with R14 385, school expenditure with R13 754, vegetables with R13 674 and furniture with R13 462 per month for the 132 households. The smallest expenditure was the R176 for licenses, followed by R225 for gambling, R240 for electricity, R350 for other expenses, R530 for loans and R660 for rent per month by the 132 households. The relatively low expenditure per household provides further evidence of the level of poverty in the sample area.

According to Statistics South Africa (2008b:13) if alcoholic beverages and tobacco are excluded, just about one in every four rand $(24,8 \%)$ spent by rural households in South Africa was on foodstuffs and non-alcoholic beverages in $2005 / 06$, while this figure was $12,5 \%$ in the urban areas. Of the nine provinces, households in Limpopo and the Eastern Cape spent the highest percentage of their household consumption expenditure on food and non-alcoholic beverages. The figures are $22,1 \%$ and $17,8 \%$, respectively. Bread, cereal and meat were the major components of food costs, especially among black African households. Together, these components accounted for $10,9 \%$ of the total household consumption expenditure of black African households.

The households in the survey area conform to a large degree to the findings of Statistics South Africa for the broader rural areas in South Africa and Limpopo in particular.

Table 1: Expenditure in selected rural households in 2007 ( $N=132)$, Rand values

\begin{tabular}{|l|l|l|l|l|l|l|l|l|l|l|l|l|}
\hline $\begin{array}{l}\text { Categories } \\
\& \text { answers }\end{array}$ & 0 & \multicolumn{2}{l|}{$1-100$} & \multicolumn{2}{l|}{$101-200$} & \multicolumn{2}{l|}{$201-300$} & \multicolumn{2}{l|}{$\begin{array}{l}301 \text { and } \\
\text { more }\end{array}$} & \multicolumn{2}{l|}{$\begin{array}{l}\text { Total and } \\
\text { average }\end{array}$} \\
\hline & $\mathrm{N}$ & $\mathrm{N}$ & Value & $\mathrm{N}$ & Value & $\mathrm{N}$ & Value & $\mathrm{N}$ & Value & \multicolumn{2}{l|}{ Total } & Ave \\
\hline $\begin{array}{l}\text { Maize } \\
\text { meal }\end{array}$ & 2 & 9 & 691 & 30 & 5012 & 84 & 22899 & 7 & 3630 & 32232 & 244,2 \\
\hline Bread & 10 & 89 & 4229 & 22 & 3388 & 8 & 2240 & 3 & 1060 & 10917 & 82,7 \\
\hline $\begin{array}{l}\text { Meat/ } \\
\text { chicken }\end{array}$ & 16 & 72 & 3936 & 29 & 4878 & 10 & 2710 & 5 & 2150 & 13674 & 103,6 \\
\hline Vegetables & 47 & 72 & 3023 & 10 & 1240 & 3 & 900 & - & - & 5163 & 39,1 \\
\hline Milk & 81 & 46 & 1385 & 4 & 680 & 1 & 250 & - & - & 2315 & 18,0 \\
\hline Other food & 30 & 49 & 3136 & 31 & 5013 & 10 & 2950 & 12 & 5690 & 16789 & 127,2 \\
\hline Fuel & 72 & 52 & 2754 & 5 & 782 & 1 & 300 & 2 & 1175 & 5011 & 38,0 \\
\hline $\begin{array}{l}\text { Other } \\
\text { energy }\end{array}$ & 95 & 25 & 894 & 5 & 790 & 7 & 1870 & - & - & 3554 & 27,1 \\
\hline Taxi & 48 & 72 & 3693 & 7 & 1088 & 2 & 500 & 3 & 1700 & 6981 & 53,3 \\
\hline $\begin{array}{l}\text { Other } \\
\text { transport }\end{array}$ & 119 & 13 & 573 & - & - & - & - & - & - & 573 & 4,4 \\
\hline $\begin{array}{l}\text { Cleaning } \\
\text { materials }\end{array}$ & 8 & 111 & 5882 & 12 & 1690 & - & - & 1 & 500 & 8072 & 61,6 \\
\hline $\begin{array}{l}\text { Cigarettes } \\
\& \text { tobacco }\end{array}$ & 117 & 11 & 333 & 4 & 660 & - & - & - & - & 993 & 7,6 \\
\hline $\begin{array}{l}\text { Alcoholic } \\
\text { drinks }\end{array}$ & 125 & 4 & 315 & 1 & 150 & 2 & 600 & - & - & 1065 & 8,2 \\
\hline Rent & 128 & 1 & 10 & 2 & 350 & 1 & 300 & - & - & 660 & 5,0 \\
\hline Water & 127 & 5 & 240 & - & - & - & - & - & - & 240 & 1,8 \\
\hline Electricity & 111 & 21 & 792 & - & - & - & - & - & - & 792 & 6,0 \\
\hline Clothing & 35 & 51 & 3185 & 29 & 4810 & 9 & 2560 & 8 & 3830 & 14385 & 109,0 \\
\hline School & 81 & 30 & 1399 & 11 & 3730 & 5 & 1265 & 5 & 7360 & 13754 & 104,2 \\
\hline Burial & 44 & 72 & 3916 & 13 & 1997 & 3 & 800 & - & - & 6713 & 50,9 \\
\hline
\end{tabular}




\section{R.R Mears , P.F Blaauw

\begin{tabular}{|l|l|l|l|l|l|l|l|l|l|l|l|}
\hline society & & & & & & & & & & & \\
\hline Medical & 128 & 1 & 40 & 2 & 350 & 1 & 300 & - & - & 690 & 5,2 \\
\hline Insurance & 125 & 4 & 215 & 2 & 320 & - & - & 1 & 400 & 935 & 7,1 \\
\hline Gambling & 130 & 1 & 25 & 1 & 200 & - & - & - & - & 225 & 1,7 \\
\hline Savings & 115 & 4 & 220 & 5 & 900 & 2 & 600 & 6 & 3200 & 4920 & 37,6 \\
\hline Licences & 130 & 1 & 26 & 1 & 150 & - & - & - & - & 176 & 1,3 \\
\hline $\begin{array}{l}\text { Cell } \\
\text { phones }\end{array}$ & 57 & 69 & 2650 & 5 & 740 & - & - & 1 & 500 & 3890 & 29,5 \\
\hline $\begin{array}{l}\text { Motor } \\
\text { finance }\end{array}$ & 130 & - & - & 1 & 150 & - & - & 1 & 3800 & 3950 & 29,9 \\
\hline Loans & 128 & 2 & 80 & 1 & 150 & 1 & 300 & - & - & 530 & 4,0 \\
\hline Furniture & 99 & 10 & 252 & 5 & 980 & 4 & 1070 & 14 & 11160 & 13462 & 102,0 \\
\hline $\begin{array}{l}\text { Other } \\
\text { expenses }\end{array}$ & 130 & - & - & 2 & 350 & - & - & - & - & 350 & 2,7 \\
\hline Agriculture & 126 & 2 & 8 & 2 & 360 & - & - & 1 & 1000 & 1368 & 10,4 \\
\hline
\end{tabular}

Source: Survey data

\section{THE RELATIONSHIP BETWEEN EMPLOYMENT STATUS AND EDUCATION LEVELS}

This section shows that the level of education in these rural villages affects the employment status, and therefore also the level of poverty. Table 2 and Figure 1 show that the education levels are the highest for the economically active population, which includes the unemployed.

Table 2: Cross-tabulation of employment status and qualifications of the population in $2007^{2}$

\begin{tabular}{|l|l|l|l|l|l|l|l|l|l|l|}
\hline $\begin{array}{l}\text { Employment } \\
\text { status and } \\
\text { Qualification }\end{array}$ & \multicolumn{2}{l}{$\begin{array}{l}\text { Formally } \\
\text { employed }\end{array}$} & \multicolumn{2}{l|}{$\begin{array}{l}\text { Informally } \\
\text { active }\end{array}$} & \multicolumn{3}{l|}{ Unemployed } & \multicolumn{2}{l|}{$\begin{array}{l}\text { Not } \\
\text { economically } \\
\text { active }\end{array}$} & \multicolumn{2}{|c|}{ Total } \\
\hline Results & $\mathrm{N}$ & $\%$ & $\mathrm{~N}$ & $\%$ & $\mathrm{~N}$ & $\%$ & $\mathrm{~N}$ & $\%$ & Active & Total \\
\hline No schooling & 7 & 13,5 & 9 & 17,0 & 15 & 10,3 & 147 & 31,5 & 178 & 24,8 \\
\hline Grade 1-7 & 22 & 42,3 & 19 & 35,8 & 41 & 28,1 & 207 & 44,4 & 289 & 40,3 \\
\hline Grade 8-11 & 9 & 17,3 & 14 & 26,4 & 53 & 36,3 & 85 & 18,2 & 161 & 22,5 \\
\hline $\begin{array}{l}\text { Grade12 and } \\
\text { higher }\end{array}$ & 14 & 26,9 & 11 & 20,8 & 37 & 25,3 & 27 & 5,8 & 89 & 12,4 \\
\hline Total & 52 & 100 & 53 & 100 & 146 & 100 & 466 & 100 & 717 & 100 \\
\hline Missing cases & - & & 1 & & 3 & & 19 & & & \\
\hline
\end{tabular}

Source: Survey data

They also show that the qualifications of the non-economically active are higher than the average for no schooling and primary schooling, while they are much lower than the average for the secondary and tertiary education categories. In their analysis of the poverty trap in KwaZulu-Natal, May and Woolard (2007) and Gumede (2008:13) attribute the inability to overcome poverty to low initial education levels. This suggests that education is therefore an important route out of poverty for many people, including this sample population.

${ }^{2}$ Of the total population of 740 residents, 23 of the qualifications were not supplied, left blank or captured as a dash instead of zero. Therefore, they are not reflected in the cross-tabulations of the employment status and education levels. 
Figure 1 also shows a high dependency ratio, where the non-economically active and unemployed are dependent on the small number who are formally and informally employed. In addition, the percentage of people who have passed only Grade 5 or lower was 52,6 percent. This means that more than half of the total population can be considered functionally illiterate (Mears et al. 2008:11; Gumede 2008:17).

Figure 1: Cross-tabulation of employment status and qualifications of the population in

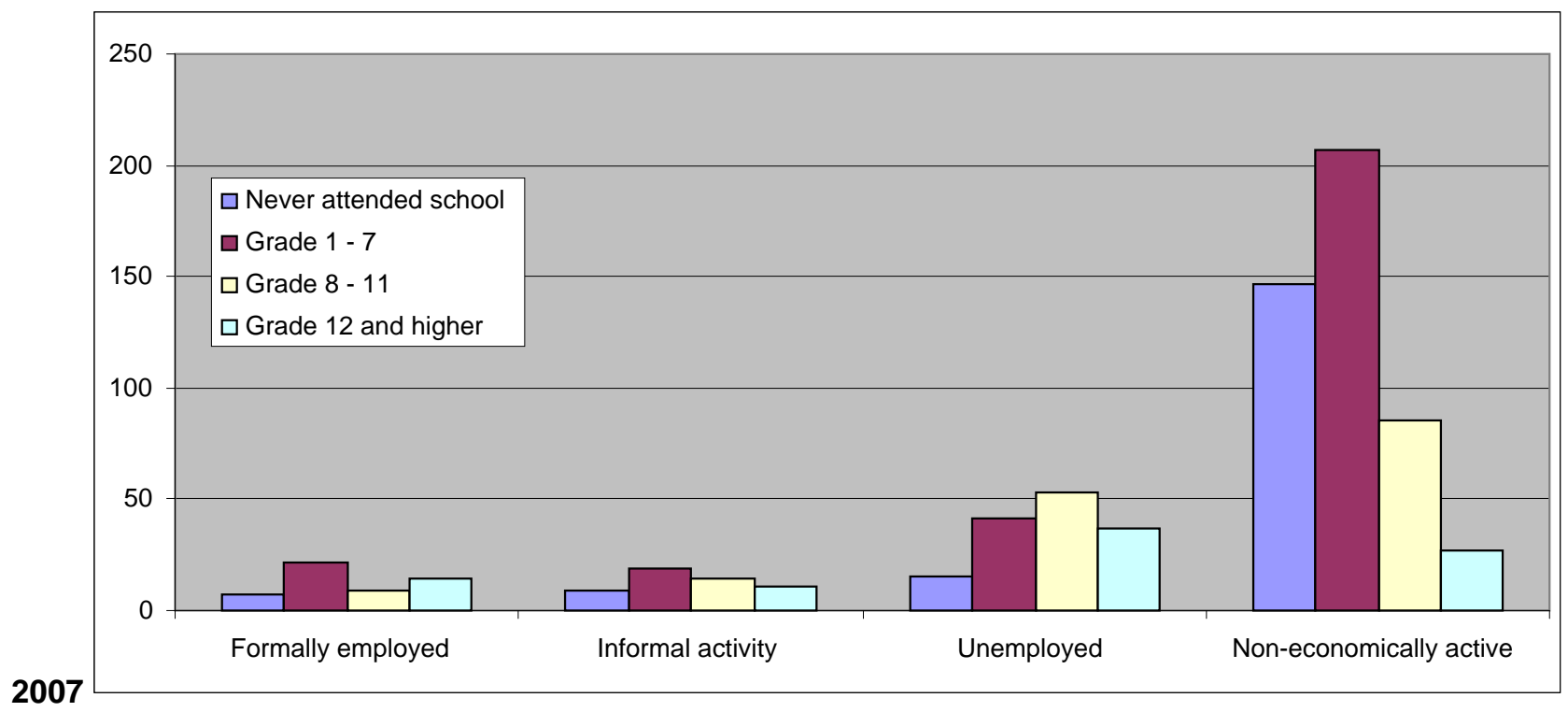

Source: Table 2

The next section shows that the largest number of income earners come from the non-economically active population.

\section{INTERPRETATION OF INCOME, EXPENDITURE, MINIMUM LIVING LEVELS (MLL) AND THE POVERTY GAP IN 2007}

An important requirement for a good income measure is that it should not change when incomes change proportionally (Theil 1967:92). The Gini-concentration ratio is a popular measure of income inequality. This section therefore uses the income, expenditure and the MLL to determine the level of poverty and the poverty gap in the survey area. The MLL used here are from Annexure 1 and are defined and explained in the research methodology.

The details of all households are shown in Table 3, including the totals and averages of the five quintiles. Table 3 also shows the income, expenditure and MLL per household, which are arranged in ascending order by income to determine the data for the poorest quintiles. The 132 households were divided into five equal parts, of 20 percent or quintiles for this purpose. The last row in Table 3 shows that when the average income of R2 015 is deducted from the average expenditure of R1 322 the result is a surplus income of R693 per household on average. However, this does not give the true or real picture of the plight of many households, especially those in the poorest quintiles. The income minus expenditure calculation is positive for only five of the 26 households in the first quintile (Survey data). Table 3 is a summary of the 26 households per quintile. 
Table 3 shows that 20 percent of the population with the lowest income, or quintile 1 , receives only 4,2 percent of the total income, while the fifth quintile receives 50,5 percent. The first quintile spends 9,6 percent of the total expenditure, while the fifth quintile spends 27,6 percent. This is mainly because the lowest income group spends most of its income on consumer goods. However, in this case quintiles 1 and 2 spend more than their total income on consumer goods, which is not possible unless they use their savings or have other sources of income not reported. Although every effort was made to collect the correct and full income, this was not always successful. One of the errors in quintile 1 is that two people refused to divulge their income, due to the sensitivity of the data (survey data). Some households could also have indicated more

Table 3: Totals and averages of income, expenditure and MLL per household and calculation of the poverty gap per quintile in 2007 (percentage of total in brackets)

\begin{tabular}{|l|l|l|l|l|l|l|}
\hline Totals & Y & E & Y-E & MLL & Y-MLL & E-MLL \\
\hline Quintile 1 & $11090(4,2)$ & $16829(9,6)$ & -5739 & 57846 & -46756 & -41017 \\
\hline Quintile 2 & $24610(9,2)$ & $29256(16,8)$ & -4646 & 60690 & -36080 & -31434 \\
\hline Quintile 3 & $37460(14,1)$ & $34834(20,0)$ & 2626 & 69865 & -32405 & -35031 \\
\hline Quintile 4 & $58430(22,0)$ & $45376(26,0)$ & 13054 & 76332 & -17902 & -30956 \\
\hline Quintile 5 & $134383(50,5)$ & $48249(27,6)$ & 86134 & 75817 & 58566 & -27568 \\
\hline Total & $\mathbf{2 6 5 9 7 3 ( 1 0 0 )}$ & $\mathbf{1 7 4 5 4 4 ( 1 0 0 )}$ & $\mathbf{9 1 4 2 9}$ & $\mathbf{3 4 0 5 5 0}$ & $-\mathbf{7 4 5 7 7}$ & -166006 \\
\hline Averages & & & & & & \\
\hline Quintile 1 & $427(21,2)$ & $647(48,9)$ & -221 & 2225 & -1798 & 1578 \\
\hline Quintile 2 & $911(45,2)$ & $1084(82,0)$ & -172 & 2248 & -1336 & -1164 \\
\hline Quintile 3 & $1387(68,8)$ & $1290(97,6)$ & 97 & 2588 & -1200 & -1297 \\
\hline Quintile 4 & $2247(111,5)$ & $1745(132,0)$ & 502 & 2827 & -689 & -1191 \\
\hline Quintile 5 & $5169(256,5)$ & $1856(140,4)$ & 3313 & 2916 & 2253 & -1060 \\
\hline $\begin{array}{l}\text { Ave of } \\
\text { Total }\end{array}$ & $\mathbf{2 0 1 5 ( 1 0 0 )}$ & $\mathbf{1 3 2 2 ( 1 0 0 )}$ & $\mathbf{6 9 3}$ & $\mathbf{1 2 8 0 4}$ & $\mathbf{- 5 6 5}$ & $\mathbf{- 1 2 5 8}$ \\
\hline
\end{tabular}

Source: Survey data

expenditure than they had in fact used. Whatever the reasons, it is often the case that survey data shows these discrepancies, notwithstanding the training and standard of the research. The data was used as recorded and no adjustments were made to any of the survey data in this article.

The data shows that only 24 of the 132 households, or 18 percent, did not receive a state grant in 2007. Old age or disability pensions of R870 were paid to 60 members of households and child grants of R200 each to 183 children (Survey data). This was an injection of R88 800 or 33,4 percent of the total income of R265 973 per month to the sample population in 2007. This has contributed significantly to the alleviation of poverty in the survey area. Van den Berg, Burger, Louw and Yu (2005) show that the per capita real incomes of individuals comprising the poorest population quintiles rose by more than 30 percent during the period 2000 to 2004. The impact of social grants on the poor in South Africa is significant, since transfers increased by R22 billion during the period 2003 to 2005. Almost 12,5 million South Africans received cash transfers in 2007 (Gumede 2008:12). This excludes the social wage in terms of free basic water, electricity, subsidised or free housing, health care subsidies and more.

Quintiles 1 and 5 each contain eight households that receive no state grants, while quintile 3 has none, quintile 4 has three and quintile 2 has five households with no grants received (from the survey data). All the 
small households, with 1 and 2 members per household, fall into the first quintile or among the poorest of the poor (Survey data). This is a surprising finding, because it can be argued that the largest households with more dependants should be poorer. It seems that these poor couples and single-member households fall through the safety net, because they do not qualify for state grants due to their age and the fact that they do not have children yet.

Table 3 shows that on average the poverty gap per household, Y-MLL, decreased from minus R1 798 for quintile 1 to minus R689 for quintile 4 and is only positive at R2 253 for quintile 5 . The expenditure minus minimum living levels (E-MLL) can be used as an alternative method to measure the poverty gap, but this is not a recommended method. It shows a poverty gap for all the quintiles, which is not correct, because the income in quintile 5 is large enough to eliminate the poverty gap. Figure 2 and Table 3 show that the total poverty gap for the first 4 quintiles is R133 143, which is still an underestimation, because six households in quintile 4 show a positive

Figure 2: The poverty gap and Lorenz curve of the sample population in selected Limpopo rural villages in 2007

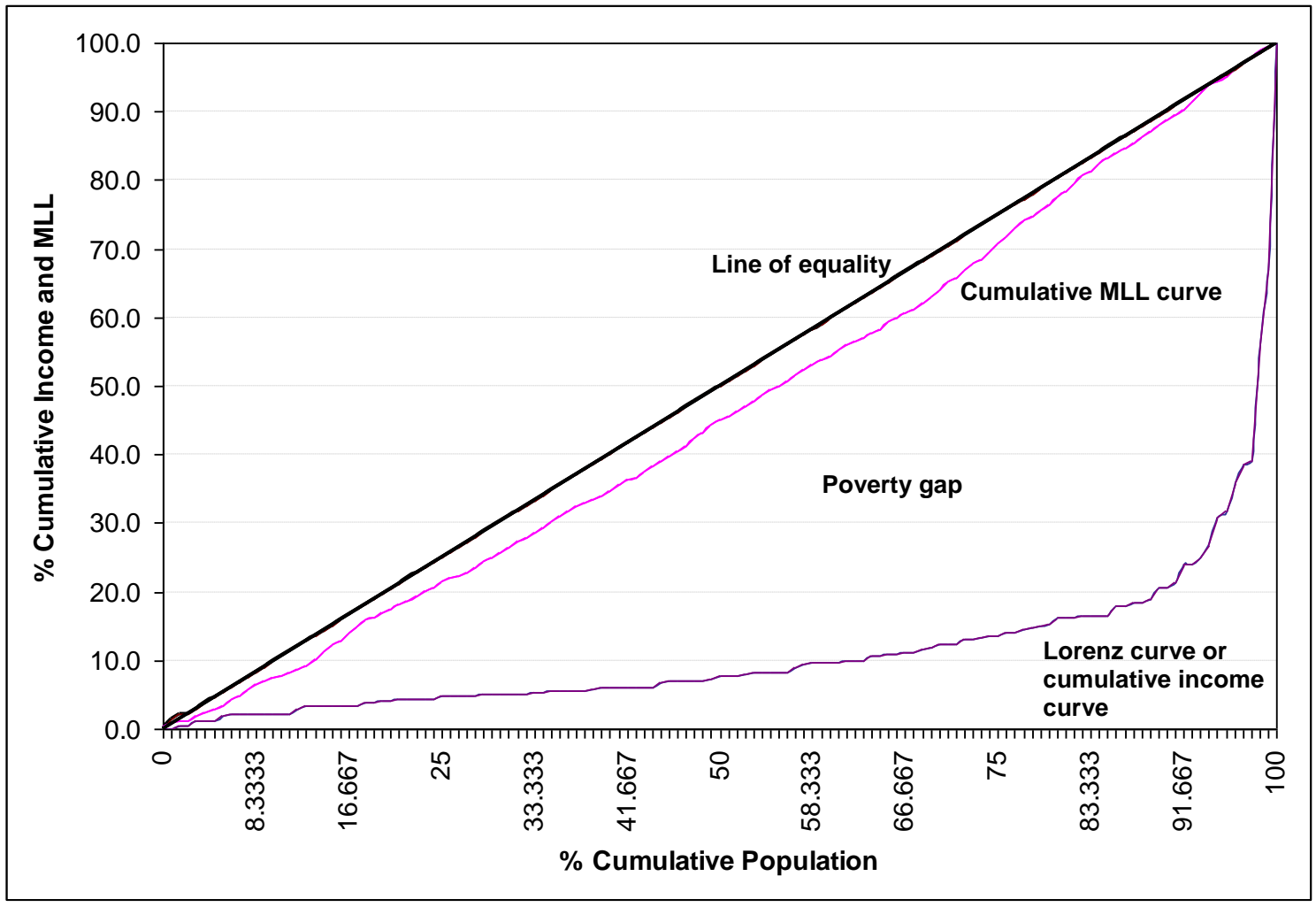

Source: Table 3 and Survey data

amount. These amounts must be added on and the households should not be used in the calculations. In addition, the four households with a poverty gap in quintile 5 must also be added to this figure (Survey data). These adjustments show that the incomes of the poor households need to be increased by more than a R1000 on average per month to lift every household out of poverty. This is purely an academic exercise, but nevertheless gives the best indication of the level of poverty in these villages. 
The Gini coefficient as an aggregate measure of inequality was also calculated from the survey data. Gini coefficients vary between 0 for perfect equality to 1 for perfect inequality (Todaro and Smith 2009). Figure 2 shows that the Lorenz curve or cumulative income of the population was 0,78 in 2007. Based on the MLL curve it was 0,07, which shows that this adjustment virtually leads to perfect equality. Table 3 and Figure 2 also show that the average MLL increases from quintile 1 to quintile 5, which means that the household sizes also increase progressively as households become less poor (Survey data). This is often not the case in the more affluent communities. This is an important finding for this deep rural and poor community. The average income per household increases progressively from quintile 1 to quintile 5 . The average expenditure shows similar behaviour, but is much less progressive than average income (Survey data).

The poverty gap per household, Y-MLL, is shown in Table 3 and Figure 2. It was decided that the MLL as supplied by Bijker (2008) would be used without any adjustment for the rural areas. The cost of living in the rural areas is generally higher than in urban areas for most of the items shown in Table 1, except for insurance, property and own produce. The households in the survey area do not pay for or use these items extensively. The only adjustment is shown in Annexure 1 and was effected to enable the determination of household size by means of the MLL in the calculation of Table 3.

Moreover, Figure 2 and Table 3 show the unequal income distribution, because 50 percent of the population receives only 20 percent of the income. The Minimum Living Levels (MLL) curve closes the poverty gap and in fact leads to a virtual equal distribution of income in this poor rural community. If the government were to decide on such a policy it would be a large disincentive to work, because people will receive virtually the same or better income from grants as they do currently. This will therefore not be a viable or sustainable solution to the large unemployment and poverty in these rural areas. The MLL is much higher than the income or expenditure in the sample, except for a few cases in quintile 4 and most cases in quintile 5 (Survey data). Table 3 shows that the income $(Y)$ minus MLL is on average negative R565. For expenditure (E) minus MLL it is negative R1 258. This again emphasises the extent of the poverty in the sample area and the high poverty gap of most households.

\section{EFFECTS OF STATE GRANTS ON THE DISTRIBUTION OF INCOME IN 2007}

This section expands on the income earnings of the non-economically active population. Although South Africa is a developing country, it has a large social system that caters for more than 20 percent of the total population by means of state grants. This has a significant influence on the distribution of income and on the alleviation of poverty in these Limpopo villages.

Table 4 shows the distribution of income per age category per month. Contrary to normal practice, where children do not earn income, 95 individuals in the age group 0-6 years and 122 in the age group 7-14 receive an income below R500 per month. As stated earlier, 183 of these children received a child grant of R200 in 2007 and the rest received mainly maintenance from relatives (Survey data). Only 19 of the workers received a wage of R2 001 or more. The 166 missing cases are also individuals who receive zero income and were therefore not captured by the cross-tabulations, because nothing was captured instead of a zero. 
Table 4: Distribution of income per age category per month in 2007

\begin{tabular}{|l|l|l|l|l|l|l|l|l|l|l|}
\hline $\begin{array}{l}\text { Income } \\
\text { Age } \\
\text { category }\end{array}$ & $\mathbf{N}$ & $\begin{array}{l}\mathbf{0 -} \\
\mathbf{5 0 0}\end{array}$ & $\begin{array}{l}\mathbf{5 0 1 -} \\
\mathbf{1 0 0 0}\end{array}$ & $\begin{array}{l}\mathbf{1 0 0 1 -} \\
\mathbf{2 0 0 0}\end{array}$ & $\begin{array}{l}\mathbf{2 0 0 1 -} \\
\mathbf{3 0 0 0}\end{array}$ & $\begin{array}{l}\mathbf{3 0 0 1 -} \\
\mathbf{4 0 0 0}\end{array}$ & $\begin{array}{l}\mathbf{4 0 0 1 -} \\
\mathbf{5 0 0 0}\end{array}$ & $\begin{array}{l}\mathbf{5 0 0 1} / \\
\mathbf{>}\end{array}$ & Total & Missing \\
\hline $\mathbf{0 - 6}$ & 104 & 95 & 0 & 0 & 0 & 0 & 0 & 0 & 95 & 9 \\
\hline $\mathbf{7 - 1 4}$ & 152 & 122 & 0 & 0 & 0 & 0 & 0 & 0 & 122 & 30 \\
\hline $\mathbf{1 5 - 2 0}$ & 104 & 68 & 1 & 1 & 0 & 0 & 0 & 0 & 70 & 34 \\
\hline $\mathbf{2 1 - 3 0}$ & 133 & 74 & 11 & 2 & 1 & 0 & 0 & 0 & 88 & 45 \\
\hline $\mathbf{3 1 - 4 0}$ & 88 & 45 & 15 & 11 & 2 & 1 & 0 & 2 & 76 & 12 \\
\hline $\mathbf{4 1 - 5 0}$ & 57 & 22 & 14 & 5 & 3 & 2 & 1 & 2 & 49 & 8 \\
\hline $\mathbf{5 1 - 6 0}$ & 38 & 14 & 9 & 3 & 1 & 0 & 2 & 2 & 31 & 7 \\
\hline $\mathbf{6 1 / >}$ & 46 & 1 & 38 & 4 & 0 & 0 & 0 & 0 & 43 & 3 \\
\hline Missing & 18 & - & - & - & - & - & - & - & - & 18 \\
\hline Total & $\mathbf{7 4 0}$ & $\mathbf{4 4 1}$ & $\mathbf{8 8}$ & $\mathbf{2 6}$ & $\mathbf{7}$ & $\mathbf{3}$ & $\mathbf{3}$ & $\mathbf{6}$ & $\mathbf{5 7 4}$ & $\mathbf{1 6 6}$ \\
\hline
\end{tabular}

Source: Survey data

Table 5 shows the distribution of income according to employment status in 2007. It shows that only 52 people were formally employed, while 54 were informally active. Of the total population of 740 people, 118 or 15,9 percent were unemployed. Only 17 of the unemployed received a small income of less than R500 per month. In the group who are not economically active, 125 people received no income at all, while 180 received some kind of income, mainly in the form of state grants. This cross-tabulation only captures 180 people, while Table 5 captures 217 in the age group 0-14 alone. Although the income is generally very low in these rural villages, only two people received more than R2 001 in the informal sector, while no unemployed or non-economically active people received more than $\mathrm{R} 2000$. This section shows that of the 485 noneconomically active people in the sample, more than 364 or 75 percent receive an income, mainly in the form 
Table 5: Distribution of income by employment status in 2007

\begin{tabular}{|c|c|c|c|c|c|c|c|c|c|c|}
\hline \multirow{2}{*}{$\begin{array}{l}\text { Employ- } \\
\text { ment } \\
\text { status/ } \\
\text { Income } \\
\text { category }\end{array}$} & \multicolumn{2}{|c|}{$\begin{array}{l}\text { Formally } \\
\text { employed }\end{array}$} & \multicolumn{2}{|c|}{$\begin{array}{l}\text { Informally } \\
\text { active }\end{array}$} & \multicolumn{2}{|c|}{ Unemployed } & \multicolumn{2}{|c|}{$\begin{array}{l}\text { Not- } \\
\text { economically } \\
\text { active }\end{array}$} & \multicolumn{2}{|c|}{ Total } \\
\hline & $\mathbf{N}$ & Value & $\mathbf{N}$ & Value & $\mathbf{N}$ & Value & $\mathbf{N}$ & Value & $\mathbf{N}$ & Value \\
\hline 0 & 0 & - & 2 & - & 99 & - & 125 & - & 226 & - \\
\hline $1-500$ & - & - & 28 & 8340 & 17 & 4420 & 180 & 35803 & 225 & 48563 \\
\hline $501-1000$ & 19 & 15510 & 15 & 12240 & 2 & 1770 & 56 & 48780 & 92 & 78300 \\
\hline $1001-2000$ & 16 & 24450 & 7 & 10700 & 0 & - & 3 & 4210 & 26 & 39360 \\
\hline 2001-3000 & 6 & 16250 & 1 & 2500 & 0 & - & 0 & - & 7 & 18750 \\
\hline $3001-4000$ & 3 & 10600 & 0 & - & 0 & - & 0 & - & 3 & 10600 \\
\hline $4001-5000$ & 1 & 5000 & 0 & - & 0 & - & 0 & - & 1 & 5000 \\
\hline $5001 />$ & 7 & 53500 & 1 & 10000 & 0 & - & 0 & - & 8 & 63500 \\
\hline Total & 52 & 125310 & 54 & 43780 & 118 & 6190 & 364 & 88793 & 588 & 264073 \\
\hline
\end{tabular}

Source: Survey data

of state grants. Nevertheless, better education is a better long-term route out of poverty than the child grant and free medical services for mothers and children, which often encourages poor people to have more children, placing an additional burden on the community. The latter option is not a sustainable one for a developing country.

\section{CONCLUSIONS AND RECOMMENDATIONS}

The community studied in this paper is improving or investing in housing, mainly on a cash basis as money becomes available. Only four households had small loans totaling R530 or R4 per month per household on average. Although the expenditure was recorded in detail, the responses were often poor, as can be seen from the 35 households who reported no expenditure on clothing.

The total expenditure was R174 544 or R1 322 on average per month per household for the 132 households in 2007. This is an average expenditure of R236 per person for the 740 members of these households. The largest expenditure is on their staple diet of maize meal at R32 232 or 18,5 percent of the total expenditure. The expenditure pattern is thus further evidence of the level of poverty in the area.

The relatively poor educational attainment of the non-economically active population compared to the small economically active population is debatably the largest contributor to poverty. Better education is the most effective way of overcoming poverty and of closing the poverty gap. This suggests that education is the route out of poverty, rather than the child grant and free medical services for mother and child, which often encourages poor people to have more children.

This research shows that only 18 percent of the sample households did not receive a state grant in 2007. This was an injection of R88 800 or 33,4 percent of the total income of R265 973 per month to the Limpopo community in 2007. This, however, excludes the social wage in terms of free basic water, electricity, subsidised or free housing, health care subsidies and other support to poor people and rural communities. Nevertheless, the community as a whole remains very poor and below the poverty line. 
The effects of state grants on the distribution of income in this sample were significant in 2007. In the group who are not economically active more than 364 or 75 percent of the people received an income. Only 52 people received a wage from the formal sector and 54 from informal activity. Only 19 of the workers received a wage of R2 001 per month or more. An important policy implication is that any expansion of the social grants in order to provide a permanent income for the unemployed will not be a wise one, as it is not sustainable in the long run. The ultimate aim must still be to absorb the unemployed into the labour market.

Although the alleviation of poverty receives high priority in government policy-making, there is limited data to measure the successes or failures of the policies to alleviate poverty. Data must be disaggregated between rich and poor so that better measurements can be done. This research is an example, on a very small scale, of what data would be needed to measure poverty and the poverty gap. The development of an official single definition of the poor and a formal policy line is also urgently needed to provide clarity and to ensure that all research projects use standardised terms and forms of measurement.

South Africa is investigating an official single definition of the poor, although various departmental definitions exist. South Africa also does not yet have a formal poverty line. Moreover, no distinction is made in official data between the poor and the rich. This makes comparisons between rich and poor or between such incomes in rural and urban areas very difficult. More disaggregated data is therefore needed to inform policy decisions to alleviate poverty in South Africa.

All the small households with one or two members per household fall in the first quintile or among the poorest of the poor. These poor couples or single-member households fall through the safety net, because they do not qualify for state grants due to their age and the fact that they do not have children. This finding needs further research to inform the redistribution policy.

The Minimum Living Levels indicator is much higher than the income or expenditure in the sample except for a few cases in quintile 4 and most in quintile 5. Quintile 1, or the poorest 20 percent of the population, receives only 4,2 percent of the total income, while the fifth quintile receives 50,5 percent. However, the first quintile spends 9,6 percent of the total expenditure, while the fifth quintile spends 27,6 percent. The average MLL increases from quintile 1 to quintile 5, which means that the household sizes also increase progressively. This is an important finding for this deep rural and poor community. The determination of the poverty gap is purely an academic exercise, but gives the best indication of the level of poverty in these villages. Based on the assumed MLL, an estimated R135 000 would be needed per month to lift all the poor in the sample population to their MLL, or out of poverty.

This shows that the poverty gap can only be calculated per household and not in an aggregate way for the community. The MLL only gives an indication of the poverty in a community, but an ad hoc calculation of each household has to be done to determine whether the household qualifies for a grant, subsidy or other poverty relief measures.

Differences in terms of poverty and income distribution between urban and rural areas in South Africa are well documented. It is therefore expected that the income and expenditure patterns in these rural villages differ from those of poor suburbs in urban areas. A comparison of these findings with a similar number of poor households in Soweto is envisaged as part of future research emanating from these results. The same research will also be conducted in a small rural village in the Eastern Cape. A comparison of the two rural areas with each other and with Soweto can then be used to obtain a wider policy angle on the results. These research experiences can lay a valuable foundation for a methodology paper that can direct further microstudies into this complex and critical challenge for our society. 


\section{REFERENCES}

ATKINSON, AB. (1970). On the measurement of inequality. Journal of Economic Theory, 2(3):244-263.

BHORAT, H. NAIDOO, P. and VAN DER WESTHUIZEN, C. (2006). Shifts in non-income welfare in South Africa: 1993-2004. Cape Town: Development Policy Research Unit, University Of Cape Town.

BIJKER, G. (2008). Minimum Living Levels (MLL) table provided by email on 1 September 2008. Centurion: Business Intelligence Division of Global Insight Southern Africa.

BOSCH, A. (2008). An empirical analysis of the adequacy of the infrastructure delivery rate to address poverty in South Africa, unpublished masters dissertation, Department of Economics and Econometrics, University of Johannesburg.

FOSTER, J. GREER, J. and THORBECKE, E. (1984). A class of decomposable poverty measures, Econometrica, 52(3):761-765.

GUMEDE, V. (2008). Poverty and "second economy" in Southern Africa: an attempt to clarify applicable concepts and quantify extent of relevant challenges. DPRU Working Paper, 08/133, June 2008. Development Policy Research Unit. Available on http://www.commerce.uct.ac.za/dpru/

HSRC. (2004). Poverty in South Africa, Fact Sheet No: 1, 26 July 2004. Pretoria: Human Sciences Research Council.

MAGASELA, W. (2005). Constructing a National Poverty Line for South Africa: issues for consideration. National Labour and Economic Development Institute, unpublished discussion paper.

MAKGETLA, NS. (2004). Women and the Economy. Available on http://cc.msnscache.aspx?q

MARTINS, JH. (2003). Minimum living levels and consumer price index: what's in a name? Development Southern Africa, 20(2):197-212.

MAY, J. and WOOLARD, I. (2007). Poverty traps and structural poverty in South Africa: reassessing the evidence from KwaZulu Natal. CPRP Working Paper, 82. Durban: University of KwaZulu Natal.

MEARS, RR. and LEVIN, M. (1994). Demographic Characteristics of the Population of Greater Soweto: 1993. Research Report No.42. Soweto: Employment Research Unit of Vista University.

MEARS, RR. (2007). Informal Interviews and Observations in Tshithanzhe on 9 July 2008, and at the Big Baobab Tree on 11 July 2007, as well as in the surveyed villages during the survey.

MEARS, RR. JAGALS, P. GREYLING, L. and BLAAUW, PF. (2008). Demographic Characteristics of Selected Rural Villages in the Nwanedi River Basin. Paper read at the $2^{\text {nd }}$ Biennial International Conference on creating, developing and delivering value in Africa in the global context. Value 2008, Sun City, North West Province on 26-28 May 2008.

METH, C. and DIAS, R. (2003). Increases in poverty in South Africa: 1999 - 2002. Cape Town: Development Policy Research Unit, University of Cape Town.

MOHR, P. (2010). Understanding the economy. $1^{\text {st }}$ Edition. Pretoria: Van Schaik. 
RAVALLION, M. and LOKSHIN, M. (2006). On the consistency of poverty lines. In De Janvry, A. \& Kambur, R. (Eds). Poverty, inequality and development. Essays in honor of Erik Thorbecke. New York: Springer.

STATSSA, (2008a). Community Survey 2007: By Municipality, Population Group and Employment. Available on http://www.statsonline.gov.za/news archive/12March2008 1.asp

STATSSA, (2008b). Income and expenditure of households, Statistical release P0100. Pretoria: Government Printer.

THEIL, H. (1967). Economics and information theory. Amsterdam: North-Holland Publishing Company.

THIRLWALL, AP. (1999). Growth and development: with special reference to developing countries. Sixth Edition. Basingstoke: Macmillan.

TODARO, MP. and SMITH, SC. (2009). Economic Development. Tenth Edition. Harlow: Addison-Wesley.

TREGENNA, F. (2010). What are the distributional implications of halving poverty in South Africa? Paper delivered at a Departmental seminar of the Department of Economics and Econometrics, University of Johannesburg, 29 July 2010.

VAN DEN BERG, S. BURGER, R. LOUW, M. and YU, D. (2005). Trends in poverty and inequality since the political transition. Stellenbosch Economic Working Papers, 1/2005 (online). http://www.ber.sun.ac.za/downloads/2005/workingpapers/ WP-01-2005.pdf.

VDM, (2006). Integrated Development Plan Review for 2005/2006 Financial Year. Thohoyandou: Complied by PIMS for the Vhembe District Municipality. Accessed from Districts and Municipalities.htm; Vhembe_District_Municipality_IDP.pdf in April 2007.

WOOLARD, I. and LEIBBRANDT, M. (1999). Measuring poverty in South Africa. Development Policy Research Unit, University of Cape Town. 
R.R Mears ,

Levels of poverty and the poverty gap in rural Limpopo

P.F Blaauw

Annexure 1: Minimum Living Level tables for 1996 and 2007

\begin{tabular}{|c|c|c|c|}
\hline Household Size & 1996 & 2007 & \multirow{9}{*}{$\begin{array}{l}\text { Supplied by Bijker up to here } \\
\text { and kept } 8 \text { or more the same. }\end{array}$} \\
\hline 1 & 443 & 1,023 & \\
\hline 2 & 544 & 1,261 & \\
\hline 3 & 726 & 1,635 & \\
\hline 4 & 903 & 1,998 & \\
\hline 5 & 1,084 & 2,380 & \\
\hline 6 & 1,277 & 2,786 & \\
\hline 7 & 1,451 & 3,156 & \\
\hline $8+$ & 1,770 & 3,752 & \\
\hline 9 & & 3,852 & \multirow{5}{*}{$\begin{array}{l}\text { This is useful to know the size } \\
\text { of the household in calculating } \\
\text { Table } 3 \text {. Adapted by adding } \\
\text { R100 for each additional } \\
\text { member of the household to } \\
\text { distinguish the size of a } \\
\text { household using MLL. }\end{array}$} \\
\hline 10 & & 3,952 & \\
\hline 11 & & 4,052 & \\
\hline 12 & & 4,152 & \\
\hline 13 & & 4,252 & \\
\hline
\end{tabular}

Source: Bijker 2008 and adapted for this survey 